\title{
THE IMPACT OF COMMODITY PRICES, INTEREST RATE AND EXCHANGE RATE ON STOCK MARKET PERFORMANCE: AN EMPIRICAL ANALYSIS FROM MALAYSIA
}

\author{
NORHAFIZA NORDIN \\ SABARIAH NORDIN \\ RUSMAWATI ISMAIL \\ School of Economics, Finance and Banking \\ UUM College of Business
}

\begin{abstract}
This paper examines the impact of commodity prices (palm oil price, oil price, and gold price), interest rate, and exchange rate on the Malaysian stock market performance. Employing the bounds test approach, the results of the study showed cointegrating relationships among variables. Specifically, the results revealed a significant influence of palm oil price on the stock market index. However, no significant influence was observed for both the oil price and gold price. Interest rate and exchange rate showed significant influences, which are consistent with past empirical studies. One important policy implication from this study is that the authorities should also pay attention to the effect of commodity prices, in addition to macroeconomic variables, in implementing relevant polices, as they may have a negative impact on the Malaysian stock market.
\end{abstract}

Keywords: Stock price behaviour, commodity prices, macroeconomic variables, bounds test.

\section{Introduction}

A stock market plays a major role in contributing to the economic growth and development of a country. In fact, the performances of stock market indices have been commonly used to reflect the general performance of a country's economic condition. Specifically, a rising stock market index during a stock market boom is associated with a positive economic condition. Capital Asset Pricing Model (CAPM) and Arbitrage Pricing Theory (APT) are two prominent theories that are often used to explain the performance of stock returns. According to CAPM, stock returns are solely determined by market return. In contrast to CAPM, APT stated that stock returns are influenced by macroeconomic variables rather than market return only. APT, that was originally formulated by Ross (1976), challenges the well known CAPM which argued that well-diversified investors should only be concerned about market risk. APT can provide a more realistic explanation to the variations in stock prices as it allows for a wider selection of various factors that determine stock return. For that reason, APT has become a significant theory in explaining the impact of macroeconomic variables on stock returns.

The purpose of this study was to examine the impact of commodity prices in addition to two selected macroeconomic variables on stock performance. Specifically, this study examined if the Malaysian stock market returns are influenced by changes in the price of palm oil, the price of oil, the price of gold, interest rate, and exchange rate. The selection of palm oil price was based on the fact that the palm 
oil industry is one of the major sub-sectors of agricultural industry for Malaysia. The importance of palm oil is evidenced, as it was reported by the Malaysian Palm Oil Council (MPOC) that currently, Malaysia has accounted for $39 \%$ of the world palm oil production and $44 \%$ of the world's export. As for the inclusion of oil price and gold price, past empirical studies showed that there is a significant impact by both of them on stock market performance (Wang, Wang, \& Huang, 2010; Kapusuzoglu, 2011; Abdul Hadi, Yahya, \& Shaari, 2009; Valadkhani, Chancharat, \& Havie, 2009). This study also took into consideration two prevalent determinants of stock market index, namely interest rate, and exchange rate which have been employed extensively in past empirical studies (Ibrahim \& Wan Yusoff, 2001; Maysami, Howe, \& Hamzah, 2004; Rahman, Sidek \& Tafri, 2009; Patel, 2012; Bekhet \& Mugableh, 2012).

In summary, this study attempted to: (1) investigate the relationship between Malaysian stock returns and commodity prices, namely the price of palm oil, oil and gold, and (2) investigate the relationship between Malaysian stock returns and macroeconomic variables, namely the interest and the exchange rates.

The remainder of this paper is organised as follows. Section 2 critically discusses the literature review. Section 3 describes the data and methodology employed. This is then followed by Section 4, which presents and discusses the findings. Finally, Section 5 concludes the paper.

\section{Literature Review}

\section{Theories}

\section{Arbitrage Pricing Theory}

Arbitrage Pricing Theory (APT) is a theory that demonstrates the price of an asset given relevant risks. APT justifies that investors require different rates of return from different securities because each asset has different levels of riskiness. If the risk is priced inconsistently across the securities, then there exists an arbitrage opportunity. Arbitrageurs will take advantage of this opportunity until the market returns to equilibrium. In general, APT can be expressed as:

$R_{i t}=r f_{t}+\beta_{i} X_{t}+\varepsilon_{t}$

Where $R_{i t}$ is the return of stock $i$ at time $t$, $r f$ is the risk free interest rate at time $t$, and $X$ is a vector of predetermined economic factors at time $t$. Meanwhile, $\beta_{i}$ measures the sensitivity of stock to changes that happen to each economic factor defined by the equation and $\varepsilon$ is the error term at time $t$. Since APT does not specifically identify what variables are to be included in the model, the selection of variables is usually based on past empirical studies.

\section{Efficient Market Hypothesis Theory}

Efficient Market Hypothesis (EMH) implies that asset prices promptly reflect all available information. In an efficient market, the stocks are fairly priced. This is because once the information becomes available, market participants will act quickly based on that information. For that reason, an active investment strategy is useless because it will not result in any superior profit. Three types of market efficiency are (1) weak form, (2) semi-strong form, and (3) strong form. These three forms of market efficiency are also known as the predictability, event studies, and inside information respectively (Fama, 1970; Fama, 1991).

The weak form of market efficiency asserts that asset prices integrate all relevant past information. The semi-strong form indicates that asset prices do not just reflect past information, but also other information available to the public. Finally, the strong form of market efficiency implies that asset prices do not just reflect past and public information, but also private information particularly those specifically related to the company. Given that the market is efficient, at least in the weak form of market efficiency, the return an investor earns on his or her investment cannot be predicted because it follows a random walk. 


\section{Empirical Evidence}

Numerous studies were conducted to examine the relationships between stock returns, macroeconomic variables, and commodity prices. Nevertheless, the results of these studies seemed to be influenced by the country of study, period of study, and the techniques used to carry out the study. One such study in Malaysia was a study by Rahman, et al. (2009) who examined the relationship between macroeconomic variables and stock price behaviour. The identified macroeconomic variables were industrial production index, money supply (M1 and M2), consumer price index, foreign reserves, credit aggregates, and exchange rates. Employing monthly data from January 1986 to March 2008, the findings of the study suggested that there exist statistical significant short-run and long-run relationships between money supply, interest rate, exchange rate, reserves, industrial production index, and KLSE Composite Index. In addition, their study also showed that the Malaysian stock market has stronger dynamic interaction with reserves and industrial production index as opposed to money supply, interest rate, and exchange rate. Finally, they concluded that Malaysia's macroeconomic variables are the leading indicators of stock return.

In an earlier study, Ibrahim and Wan Yusoff (2001) found that the movement of Malaysian equity prices is driven more by domestic factors (for example, money supply) than external factors (for example, exchange rate). The result of their study showed that stock price responds immediately to monetary expansion. Although the results revealed a positive relationship between money supply and stock price in the short-run but in the long-run the results showed that money supply to have a negative effect on stock price. In addition to money supply, they also tested other variables such as real output, price level, and exchange rate. They found that besides money supply, stock prices are also influenced by the three other variables. The result of their studies showed that a change in stock prices leads to changes in consumer prices. In other words, stock price acts as the leading indicator to price level changes. Besides that, their results also revealed the negative relationship between exchange rate and stock prices where currency depreciation leads to stock price decline.

In contrast to Rahman et al. (2009), Wan Mahmood and Mohd Dinniah (2009) found no long-run relationship between macroeconomic variables and stock returns in Malaysia. Lee, Boon, and Baharumshah (2001) explored the dynamic linkages between stock prices and macroeconomic fundamentals prior to the 1997 Asian crisis. Unlike Wan Mahmood and Mohd Dinniah (2009), they discovered that macroeconomic fundamentals of inflation rate, interest rate, industrial production index, money supply, exchange rates, and trade balance are vital in determining the movements of stock prices in the short-run as well as in the longrun. Their results suggested that the Composite Index, Industrial Index, Plantation Index, and Mining Index to be inflation-sensitive securities, while the Composite Index and Industrial Index are output sensitive. The trade balance was also found to significantly influence stock prices.

In a similar vein, Bekhet and Mugableh (2012) discovered that there is a cointegration relationship between macroeconomic variables of GDP, producer price index (PPI), CPI, M3 and exchange rate with the Malaysian stock market index for the period from 1977 to 2011. The PPI, CPI, exchange rate, and M3 were found to have negative relationships with the stock market index, while the GDP was found to have a positive relationship with stock market index in the long-run. For the short-run results, only GDP was found to exert a significant positive impact on the stock market index. Similarly, Mohd Nasir, Hassan, Nasir and Harun (2012) found gross domestic product, consumer price index, base lending rate, and exchange rate to be significant determinants of the Malaysian stock market return.

From a different perspective, Majid and Yusof (2009) focused their study on the Islamic stock market. They performed a study to explore the extent to which macroeconomic variables affect the Islamic stock market in Malaysia, 
post 1997 Asian financial crisis period. By employing the autoregressive distributed lag (ARDL) approach, their results suggested that real effective exchange rate, money supply of M3, Treasury bill rate, and federal fund rate of the US monetary policy should be the variables to focus on in order to stabilise the Islamic stock market and encourage more capital into the market. Unlike other studies on conventional stock market indices, they exerted a positive relationship between interest rate and the Islamic stock prices.

Similar to Majid and Yusof (2009), Hussin, Muhammad, Abu, and Awang (2012) investigated the relationships that exist between Islamic stock market and macroeconomic variables in Malaysia. Using the Vector Auto Regression (VAR) method and Kuala Lumpur Shariah Index as a proxy for Islamic stock market, they discovered that the Islamic stock prices are cointegrated with the underlying variables of industrial production index, consumer price index, money supply, Islamic interbank rate, and exchange rate. Specifically, the money supply and exchange rate revealed significant negative relationships with the Islamic index, while the industrial production index and the consumer price index revealed the opposite direction of relationships. There was no significant relationship found between the Islamic index and the Islamic inter-bank rate.

Instead of only looking at the relationship between macroeconomic variables and the composite index, Maysami, et al. (2004) examined the cointegration between macroeconomic variables and stock market's sector indices in Singapore. Particularly, they not only examined the long-run equilibrium relationships between macroeconomic variables and the Singapore stock market index, but they also examined the relationships between the variables and Singapore Exchange's Finance Index, Property Index, and Hotel Index. Their findings indicated that there was a cointegrating relationship between interest rate, industrial production, price levels, exchange rate, and money supply with Singapore's stock market in the short-run and long-run. Similar findings were revealed for the variables and Singapore Exchange's Property Index. The approach taken by Maysami, et al. (2004) was quite similar to the approach taken by Lee, et al. (2001) who used alternative indices in addition to the Composite Index. Specifically, they use Industrial Index, Plantation Index, and Mining Index.

Comparable to macroeconomic variables, studies on the impact of commodity prices on stock price performance showed some significant relationships. For instance, Abdul Hadi, et al. (2009) examined the effect of changes in crude oil price on Bursa Malaysia and Jakarta Stock Exchange. Adopting the Engle-Granger cointegration test and Error Correction Model (ECM) for the period 1986 to 2006, they found a significant positive long-term relationship between oil price and the performance of the two stock markets. The study also indicated that oil price is the leading variable or indicator for stock price changes.

Muhammad, Ghuslan, and Jusoff (2009) conducted a study to examine the long-run relationship between the Malaysian stock market and the performance of the agricultural sector. The Plantation Index, using daily data from 1990 to 2005, represented the performance of the agricultural sector. Adopting the Johansen cointegration test and Vector Error Correction Model (VECM), their results indicated that there was a positive long-run relationship between the Malaysian stock market and agricultural sector. Other studies that revealed significant relationships between commodity prices and stock returns included Sadorsky (1999), Hamilton (1983), and Patel (2012).

In conclusion, most past studies indicated the existence of cointegration relationships between macroeconomic variables, commodity prices, and stock market indices. Among the variables that were identified to have significant impact on stock prices include the interest rate, inflation rate, exchange rate, industrial production index, money supply, and oil price. 


\section{Data and Methodology}

This study employed the bounds test approach to examine the existence of cointegration relationships among the underlying variables of the Malaysian stock market index, interbank rate, exchange rate, and each of the selected commodity prices. This study also highlighted the long-run and short-run coefficients of the underlying variables in influencing the performance of the stock market index. The stock market index was represented by the FBMKLCI (KLCI). Other variables were the three-month interbank rate (IBR) and the exchange rates of RM/USD (EXR). The prices of the commodities were represented by the price of palm oil (POIL), the price of crude oil (OIL), and the price of gold (GOLD). Specifically, this study employed monthly data for the period of 1997M12 to 2012M9. The data on interest rate, exchange rate, and stock market index were gathered from the database of DataStream, while data on prices of all commodities were gathered from the World Bank. All prices were converted into RM using the market exchange rate downloaded from the DataStream. All variables were in the logarithm form except for the interest rate.

\section{Model}

In order to assess the potential impact of palm oil, oil, and gold prices on stock market performance, three models were examined. For each model in addition to one selected commodity price, there were also interest rate (IBR) and exchange rate (EXR) used as the independent variables. Models 1,2, and 3 represented the stock market index as a function of IBR, EXR, and one selected commodity price.

Model 1

$$
\begin{aligned}
\text { LKLCI }= & \mathrm{f}(\text { IBR, LEXR, LPOIL }) \\
\text { LKLCI }= & \beta_{0}+\beta_{1} \text { IBR }_{\mathrm{t}}+\beta_{2} \text { LEXR }_{\mathrm{t}} \\
& +\beta_{3} \text { LPOIL }_{\mathrm{t}}+\varepsilon_{\mathrm{t}}
\end{aligned}
$$

\section{Model 2}

$$
\begin{aligned}
\text { LKLCI }= & \mathrm{f}(\text { IBR }, \text { LEXR, LOIL }) \\
\text { LKLCI }= & \beta_{0}+\beta_{1} I_{1 B R}+\beta_{2} \text { LEXR }_{t} \\
& +\beta_{3} \mathrm{LOIL}_{\mathrm{t}}+\varepsilon_{\mathrm{t}}
\end{aligned}
$$

\section{Model 3}

$$
\begin{aligned}
\mathrm{LKLCI}= & \mathrm{f}(\mathrm{IBR}, \mathrm{LEXR}, \mathrm{LGOLD}) \\
\mathrm{LKLCI}= & \beta_{0}+\beta_{1} \mathrm{IBR}_{\mathrm{t}}+\beta_{2} \mathrm{LEXR}_{\mathrm{t}} \\
& +\beta_{3} \mathrm{LGOLD}_{\mathrm{t}}+\varepsilon_{\mathrm{t}}
\end{aligned}
$$

Where

LKLCI $=$ Logarithm of FBMKLCI at time $t$

IBR $=3$-month interbank rate at time $t$

LEXR = Logarithm of exchange rate (RM/USD) at time $t$

LPOIL $=$ Logarithm of palm oil price at time $t$

LOIL $=$ Logarithm of oil price at time $t$

LGOLD $=$ Logarithm of gold price at time $t$

$\varepsilon=$ error term at time $t$

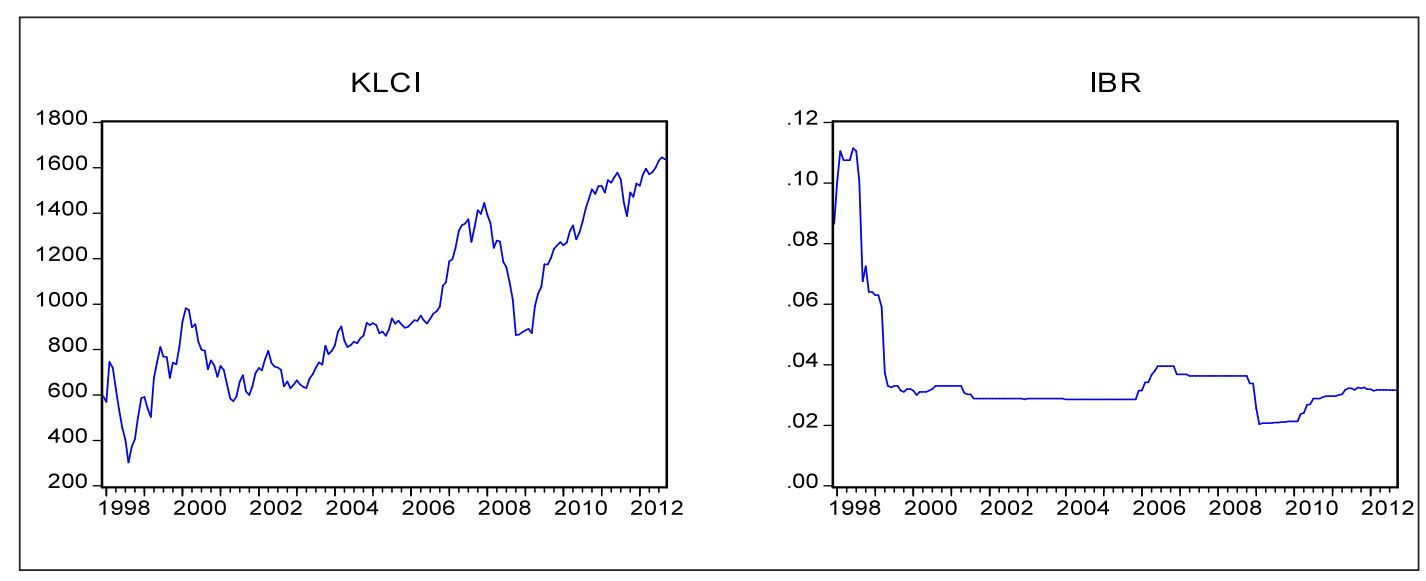

(Continued) 


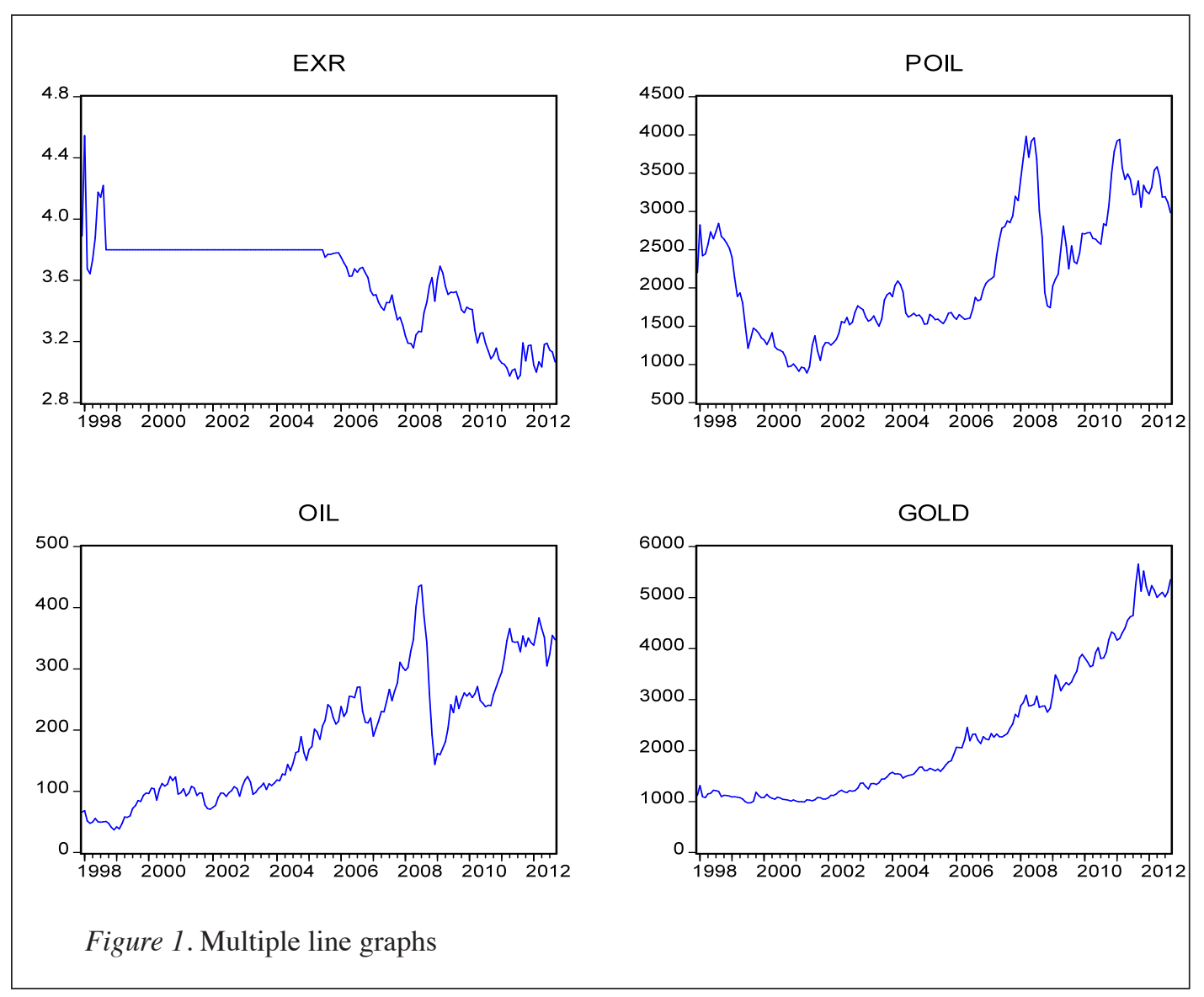

Figure 1 illustrates the behaviour of the selected variables for the study period. Most of the variables showed some kind of trend in the behaviour of the data, which indicated the nonstationarity characteristic of the data.

Table 1 highlights descriptive statistics of the underlying variables. Variances for interest rate and exchange rate were low compared to variances of the stock market index, prices of palm oil, oil, and gold, which are more than $10 \%$ (based on the squared standard deviation of each variable). Among all, the oil price showed the largest variance, followed by gold price and palm oil price.

The correlation matrix implied that the interest rate and the exchange rate had negative relationships with FBMKLCI, while prices of commodities had positive relationships with FBMKLCI (Table 2). The oil price, gold price, and the exchange rate indicated a correlation of more than $80 \%$ with the FBMKLCI.

Table 1

Descriptive Statistics

\begin{tabular}{ccccccc}
\hline & LKLCI & IBR & LEXR & LPOIL & LOIL & LGOLD \\
\hline Mean & 6.827940 & 0.035790 & 1.277164 & 7.606663 & 5.054820 & 7.571516 \\
\hline & & & & (Continued)
\end{tabular}




\begin{tabular}{lcccccc}
\hline & LKLCI & IBR & LEXR & LPOIL & LOIL & LGOLD \\
\hline Median & 6.801361 & 0.031450 & 1.329499 & 7.568430 & 5.147294 & 7.404006 \\
Maximum & 7.406170 & 0.111500 & 1.514028 & 8.289335 & 6.079539 & 8.640277 \\
Minimum & 5.713436 & 0.020300 & 1.083668 & 6.790322 & 3.617383 & 6.880491 \\
Std. Dev. & 0.346612 & 0.017869 & 0.083703 & 0.380904 & 0.619534 & 0.549926 \\
Skewness & -0.206132 & 3.130804 & -0.703968 & -0.052113 & -0.373325 & 0.409439 \\
Kurtosis & 2.671927 & 12.39912 & 2.707925 & 2.072100 & 2.122362 & 1.773438 \\
& & & & & & \\
Jarque-Bera & 2.058816 & 946.0053 & 15.33464 & 6.466310 & 9.847362 & 16.13135 \\
Probability & 0.357218 & 0.000000 & 0.000468 & 0.039433 & 0.007272 & 0.000314 \\
\hline
\end{tabular}

Table 2

Correlation Matrix

\begin{tabular}{lcccccc}
\hline & LKLCI & IBR & LEXR & LPOIL & LOIL & LGOLD \\
\hline LKLCI & 1 & & & & & \\
IBR & -0.45266 & 1 & & & & \\
LEXR & -0.87970 & 0.28763 & 1 & & & \\
LPOIL & 0.60831 & 0.18902 & -0.73407 & 1 & & \\
LOIL & 0.88695 & -0.49017 & -0.78071 & 0.54419 & 1 & 1 \\
LGOLD & 0.86587 & -0.28414 & -0.88553 & 0.77749 & 0.86410 & 1 \\
\hline
\end{tabular}

\section{Estimation Technique}

The models were than regressed using the bounds test cointegration approach. Equations (4), (5), and (6) highlighted the long-run and short-run coefficients of the model. Estimations of equations (4), (5), and (6) were derived based on Model 1, Model 2, and Model 3, respectively.

Model 1

$\triangle L K L C I_{t}=c+\beta_{I} L K L C I_{t-1}+\beta_{2} I B R_{t-1}+\beta_{3} L E X R_{t-1}$ $+\beta_{4}$ LPOIL $_{t-1}$

$+\sum_{i=1}^{p} \alpha_{1 i} \Delta L K L C I_{t-i}+\sum_{i=0}^{p} \alpha_{2 i} \Delta I B R_{t-i}+\sum_{i=0}^{p} \alpha_{3 i} \Delta L E X R_{t-i}$.

$+\sum_{i=0}^{p} \alpha_{4 i} \Delta L P O I L_{t-i}+\varepsilon_{i}$

\section{Model 2}

$\Delta L K L C I_{t}=c+\beta_{5} L K L C I_{t-1}+\beta_{6} I B R_{t-1}+\beta_{7} L E X R_{t-1}$ $+\beta_{8}$ LOIL $_{t-1}$

$+\sum_{i=1}^{p} \alpha_{5 i} \Delta L K L C I_{t-i}+\sum_{i=0}^{p} \alpha_{6 i} \Delta I B R_{t-i}+\sum_{i=0}^{p} \alpha_{7 i} \Delta L E X R_{t-i}$

$+\sum_{i=0}^{p} \alpha_{8 i} \Delta L O I L_{t-i}+\varepsilon_{i}$

Model 3

$\Delta L K L C I_{t}=c+\beta_{g} L K L C I_{t-1}+\beta_{10} I B R_{t-1}+$

$\beta_{11} L E X R_{t-1}+\beta_{12} L G O I L_{t-1}$

$+\sum_{i=1}^{p} \alpha_{9 i} \Delta L K L C I_{t-i}+\sum_{i=0}^{p} \alpha_{10 i} \Delta I B R_{t-i}+\sum_{i=0}^{p} \alpha_{11 i} \Delta L E X R_{t-i}$

$+\sum_{i=0}^{p} \alpha_{12 i} \Delta L G O L D_{t-i}+\varepsilon_{i}$ 
Where $p$ is the optimum lag length.

The hypotheses of the bounds test were as follows:

Model 1: $H_{0}: \beta_{1}=\beta_{2}=\beta_{3}=\beta_{4}=0$

(no long-run relationship)

$H_{A}: \beta_{1} \neq \beta_{2} \neq \beta_{3} \neq \beta_{4} \neq 0$

(long-run relationship exists)

Model 2: $H_{0}: \beta_{5}=\beta_{6}=\beta_{7}=\beta_{8}=0$

(no long-run relationship)

$H_{A}: \beta_{5} \neq \beta_{6} \neq \beta_{7} \neq \beta_{8} \neq 0$

(long-run relationship exists)

Model 3: $H_{0}: \beta_{9}=\beta_{10}=\beta_{11}=\beta_{12}=0$

(no long-run relationship)

$H_{A}: \beta_{9} \neq \beta_{10} \neq \beta_{11} \neq \beta_{12} \neq 0$

(long-run relationship exists)

\section{Results and Discussion}

Table 3 highlights the results of unit root tests of Augmented Dickey-Fuller (ADF), PhillipsPerron (PP), and Kwiatkowski-Phillips-SchmidtShin (KPSS). Even though the bounds test approach did not stress on the importance of knowing the order of integration of the underlying variables, there was still a need to examine the variables in terms of their stationarity in order to avoid having an $I(2)$ variable. Besides, the bounds test also required the dependent variable, in this case the stock market index, to be $\mathrm{I}(1)$. Results in Table 3 indicated that generally all underlying variables fell under the categories of $I(0)$ or $I(1)$; all variables were $I(1)$ except for the interbank rate which was $I(0)$.

Table 3

Results of Unit Root Tests

\begin{tabular}{lllll}
\hline \multicolumn{3}{c}{ Intercept } & \multicolumn{2}{c}{ Augmented Dickey-Fuller (ADF) } \\
\hline \multicolumn{1}{c}{ Level } & First Difference & Level & First Difference \\
\hline LKLCI & -1.132939 & $-10.93815^{* *}$ & -2.952335 & $-10.90700^{* *}$ \\
IBR & $-10.38426 * *$ & & $9.931318^{* *}$ & \\
LEXR & -1.786350 & $-19.50550^{* *}$ & $-4.218958^{* *}$ & \\
LPOIL & -1.693257 & $-9.177643^{* *}$ & -3.275871 & $-9.194944 * *$ \\
LOIL & -1.088544 & $-11.52673^{* *}$ & -2.616299 & $-11.49374 * *$ \\
LGOLD & 0.598333 & $-11.93107^{* *}$ & -2.818931 & $-12.13633^{* *}$ \\
\hline
\end{tabular}

\begin{tabular}{|c|c|c|c|c|}
\hline LGOLD & 0.598333 & $-11.93107 * *$ & -2.818931 & $-12.13633 * *$ \\
\hline & \multicolumn{4}{|c|}{ Phillips-Perron (PP) } \\
\hline & \multicolumn{2}{|c|}{ Intercept } & \multicolumn{2}{|c|}{ Intercept and Trend } \\
\hline & Level & First Difference & Level & First Difference \\
\hline LKLCI & -1.347394 & $-10.77138 * *$ & -3.418295 & $-10.73613^{* *}$ \\
\hline IBR & $-2.880068 *$ & & -2.440740 & $-11.58136^{* *}$ \\
\hline LEXR & -1.462598 & $-21.90043^{* *}$ & $-4.077202 * *$ & \\
\hline LPOIL & -1.460061 & $-10.68225 * *$ & -2.484788 & $-10.72007 * *$ \\
\hline LOIL & -1.205040 & $-11.52673 * *$ & -3.077284 & $-11.49374 * *$ \\
\hline LGOLD & 0.981713 & $-14.92704 * *$ & -2.676491 & $-15.54116 * *$ \\
\hline \multicolumn{5}{|c|}{ Kwiatkowski-Phillips-Schmidt-Shin (KPSS) } \\
\hline & \multicolumn{2}{|c|}{ Intercept } & \multicolumn{2}{|c|}{ Intercept and Trend } \\
\hline & Level & First Difference & Level & First Difference \\
\hline LKLCI & $1.473202 * *$ & 0.029139 & 0.061672 & 0.024554 \\
\hline
\end{tabular}




\begin{tabular}{lcccc}
\hline \multicolumn{4}{c}{ Kwiatkowski-Phillips-Schmidt-Shin (KPSS) } \\
\hline \multicolumn{2}{c}{ Intercept } & \multicolumn{2}{c}{ Intercept and Trend } \\
\hline Level & First Difference & Level & First Difference \\
\hline LPOIL & $0.972168^{* *}$ & 0.114955 & $0.185117^{*}$ & 0.061710 \\
LOIL & $1.547853^{* *}$ & 0.033727 & $0.151605^{*}$ & 0.031787 \\
LGOLD & $1.650448^{* *}$ & 0.344007 & $0.342674^{* *}$ & 0.065989 \\
\hline
\end{tabular}

Note. $*$ and $* *$ denote $5 \%$ and $1 \%$ significance levels respectively.

As indicated in Table 4, the F-statistics of $6.9883,7.0948$ and 7.2611 were greater than the I(1) critical value of 5.960 at $1 \%$ significance level. These results indicated the existence of cointegration relationships among the underlying variables. The variables displayed long-run equilibrium relationships, and they did not deviate far from each other. Short-run adjustments would restore their equilibrium relationships in the long-run.

Table 4

Results of Bounds Test for Cointegration Analysis

\begin{tabular}{lccc}
\hline Dependent variable: & \multicolumn{3}{c}{ F-statistics } \\
\hline LKLCI & Model 1 & Model 2 & Model 3 \\
\hline & $6.9883^{* * *}$ & $7.0948^{* * *}$ & $7.2611^{* * *}$ \\
\hline
\end{tabular}

Case III

(Unrestricted intercept and no trend)

\begin{tabular}{ccc} 
Narayan (2005) & $k=3$ \\
\hline Critical Value (n=80) & $I(0)$ & $I(1)$ \\
$1 \%$ & 4.568 & 5.960 \\
$5 \%$ & 3.363 & 4.515 \\
$10 \%$ & 2.823 & 3.885 \\
\hline
\end{tabular}

Note. $* * *$ represents significance at the $1 \%$ level. Critical values were cited from Narayan (2005).

Since Narayan (2005) did not provide critical values for $n=178$, critical values of $n=80$ (the maximum available number of observations) were reported as a benchmark. It was noted that the critical values of $n=178$ should be lower than the critical values of $n=80$.

Table 5 highlights the long-run and short-run coefficients of the three models. Results of the long-run estimates indicated that there were significant negative relationships between the stock market index and interest rate, as well as the exchange rate at $1 \%$ and $5 \%$ significance levels for all models. The palm oil price was found to have a significant positive influence on the stock market index at 5\% significance level, but not for the oil and gold prices. An increase in the palm oil price would lead to an increase in stock prices. Specifically, the result indicated that a $1 \%$ increase in the palm oil price would result in $0.36 \%$ increase in the FBMKLCI.

Similar results were observed for the shortrun. Results showed that there were negative significant relationships between the stock market index and interest rate as well as the exchange rate at $1 \%$ significance level for all models. 
The negative relationship between interest rate and stock return confirmed the expected result. A plausible explanation is an increase in the interest rate drives the investors away from stock markets, since it is more profitable to invest in debt. Consequently, this leads to a stock price reduction. This result supports previous results of the studies conducted by Mohd Nasir, et al. (2012), Patel (2012), and Lee, et al. (2001).

Table 5

Long-Run Elasticities and Short-Run Adjustment Coefficients

(Dependent variable: LKLCI)

\begin{tabular}{|c|c|c|c|c|c|}
\hline & Variable & Coefficient & Standard Error & t-statistic & p-value \\
\hline \multirow[t]{12}{*}{ Model 1} & Long-run elasticities & & & & \\
\hline & IBR & -13.4364 & 2.9088 & -4.6193 & 0.000 \\
\hline & LEXR & -1.7560 & 0.77786 & -2.2574 & 0.025 \\
\hline & LPOIL & 0.35753 & 0.16223 & 2.2038 & 0.029 \\
\hline & INPT & 6.8336 & 2.0864 & 3.2754 & 0.001 \\
\hline & Error correction repre & & & & \\
\hline & D(LKLCI1) & 0.18870 & 0.060041 & 3.1428 & 0.002 \\
\hline & $\mathrm{D}(\mathrm{IBR})$ & -1.8942 & 0.34222 & -5.5350 & 0.000 \\
\hline & $\mathrm{D}(\mathrm{LEXR})$ & -1.5816 & 0.19440 & -8.1357 & 0.000 \\
\hline & $\mathrm{D}$ (LPOIL) & 0.050402 & 0.021300 & 2.3663 & 0.019 \\
\hline & $\mathrm{D}(\mathrm{INPT})$ & 0.96337 & 0.40690 & 2.3676 & 0.019 \\
\hline & $\operatorname{Ecm}(-1)$ & -0.14097 & 0.028086 & -5.0194 & 0.000 \\
\hline \multirow[t]{12}{*}{ Model 2} & Long-run elasticities & & & & \\
\hline & IBR & -10.2461 & 3.9729 & -2.5790 & 0.011 \\
\hline & LEXR & -2.6751 & 0.75576 & -3.5396 & 0.001 \\
\hline & LOIL & 0.11408 & 0.11980 & 0.95225 & 0.342 \\
\hline & INPT & 10.0227 & 1.5779 & 6.3520 & 0.000 \\
\hline & Error correction repre & & & & \\
\hline & $\mathrm{D}$ (LKLCI1) & 0.24948 & 0.065225 & 3.8249 & 0.000 \\
\hline & $\mathrm{D}(\mathrm{IBR})$ & -4.9850 & 1.3781 & -3.6173 & 0.000 \\
\hline & $\mathrm{D}(\mathrm{LEXR})$ & -1.6213 & 0.18888 & -8.5838 & 0.000 \\
\hline & D(LOIL) & 0.013838 & 0.016952 & 0.81630 & 0.415 \\
\hline & D(INPT) & 1.2158 & 0.36230 & 3.3559 & 0.001 \\
\hline & $\operatorname{Ecm}(-1)$ & -0.12131 & 0.039591 & -3.0640 & 0.003 \\
\hline
\end{tabular}




\begin{tabular}{|c|c|c|c|c|c|}
\hline & Variable & Coefficient & Standard Error & t-statistic & p-value \\
\hline \multirow{12}{*}{$\begin{array}{c}\text { Model } \\
3\end{array}$} & Long-run elasticities & & & & \\
\hline & IBR & -11.3277 & 3.1420 & -3.6053 & 0.000 \\
\hline & LEXR & -1.9349 & 0.99901 & -1.9369 & 0.054 \\
\hline & LGOLD & 0.22402 & 0.14888 & 1.5047 & 0.134 \\
\hline & INPT & 7.9976 & 2.3441 & 3.4118 & 0.001 \\
\hline & Error correction repr & & & & \\
\hline & D(LKLCI1) & 0.24295 & 0.061580 & 3.9452 & 0.000 \\
\hline & $\mathrm{D}(\mathrm{IBR})$ & -4.8550 & 1.3771 & -3.5256 & 0.001 \\
\hline & $\mathrm{D}(\mathrm{LEXR})$ & -1.5600 & 0.19374 & -8.0521 & 0.000 \\
\hline & $\mathrm{D}(\mathrm{LGOLD})$ & 0.026395 & 0.018851 & 1.4002 & 0.163 \\
\hline & D(INPT) & 0.94233 & 0.38424 & 2.4525 & 0.015 \\
\hline & $\operatorname{Ecm}(-1)$ & -0.11783 & 0.032898 & -3.5816 & 0.000 \\
\hline
\end{tabular}

Note. The error correction representations imply short-run coefficients or short-run adjustment toward equilibrium.

The palm oil price showed consistent result where there was a positive significant relationship between the palm oil price and stock market index at $5 \%$ significance level. The short-run adjustment indicated that a $1 \%$ increase in the price of palm oil would lead to $0.05 \%$ increase in the FBMKLCI. There were no short-run relationships found for the prices of oil and gold. As indicated in Table 5, the error correction terms were significant at $1 \%$ significance level with the correct negative sign for all models. The error correction terms from 0.12 to 0.14 , based on the model, indicated that roughly not less than $12 \%$ of last year's deviation was corrected this year.

Table 6

Diagnostic Tests

\begin{tabular}{llcc}
\hline & & OLS Estimation & ARDL Estimation \\
\hline Model 1 & Test Statistics & LM & LM \\
\cline { 2 - 4 } & Serial Correlation & $8.8784(0.713)$ & $15.0473(0.239)$ \\
& Functional Form & $0.040275(0.841)$ & $1.8942(0.169)$ \\
& Normality & $45.9494(0.000)$ & $53.6473(0.000)$ \\
\hline
\end{tabular}

(Continued) 


\begin{tabular}{llcc}
\hline & & OLS Estimation & ARDL Estimation \\
\hline \multirow{2}{*}{ Model 2} & Test Statistics & LM & LM \\
& Serial Correlation & $12.8717(0.378)$ & $14.7824(0.254)$ \\
& Functional Form & $0.39243(0.531)$ & $2.1857(0.139)$ \\
& Normality & $46.3381(0.000)$ & $25.9627(0.000)$ \\
& Heteroscedasticity & $0.017346(0.895)$ & $19.1521(0.000)$ \\
\hline \multirow{2}{*}{ Model 3 } & Serial Correlation & $13.3538(0.344)$ & $15.2591(0.228)$ \\
& Functional Form & $0.49483(0.482)$ & $2.9699(0.085)$ \\
& Normality & $48.3152(0.000)$ & $33.0735(0.000)$ \\
& Heteroscedasticity & $0.044330(0.833)$ & $18.9148(0.000)$ \\
\hline
\end{tabular}

Note. numbers in parentheses ( ) are probabilities.

Table 6 shows the diagnostic test results for the three models based on the OLS estimation (p,p,p,p) and the ARDL estimation (p,q,r,s). As shown by the estimations, all three models failed the normality assumption. Nonetheless according to Paruolo (1997) (cited in MacDonald \& Ricci, 2003), non-normality that is caused by excess kurtosis does not affect the results. In addition to the normality assumption, the ARDL estimations also showed that the models failed the heteroscedasticity test. Nevertheless, it was not something uncommon since ARDL models permit the use of $I(0)$ and $I(1)$ variables (Shrestha \& Chowdhury, 2005).

\section{Conclusion}

This study investigated the impact of selected macroeconomic variables, namely the interest rate and exchange rate on the stock market index by particularly focusing on the Malaysian stock market. This study also examined the potential influence of commodity prices on the stock market index. They were the price of palm oil, oil, and gold to represent the commodity prices. By employing the bounds test approach, results indicated the existence of cointegration relationships for all models where each model used different commodity price. As a result of these cointegrating relationships, there might be possibilities for investors to earn excess returns. In contrast, if the market is efficient, the investors would not be able to earn any abnormal returns because the security prices will adjust rapidly to the arrival of new information, thus the current prices reflect all information about the security.

The presence of cointegration partially violates the efficient market condition which is that prices always fully reflect available information. Hence, this provides opportunity for active investors to earn abnormal returns before the variables reach their long-run equilibrium relationships. In other words, the variables employed may contain significant information that can be used to forecast stock market performance. Long-run and short-run estimations indicated the significance of interest rate and exchange rate in all models. As expected, the interest rate was found to have a negative relationship with the stock market index. The same result was observed for the exchange rate. These results further enrich the results of some past studies (Lee, et al., 2001; Bekhet \& Mugableh, 2012).

The price of palm oil was found to have a significant influence on the stock market index, positively, in the long-run as well as in the short-run. This result may reflect the importance of palm oil as one of the main commodities produced by the country. Nevertheless, the 
oil price and the gold price did not indicate any significant influence on stock market performance. One plausible explanation for the insignificant result of oil price is that fuel price is subsidized in Malaysia. The subsidised price, therefore, may eliminate or alleviate the impact of oil price movements on Malaysian firms. In other words, to some extent firms are insulated from the adverse effect of oil price changes. For example, they may only experience a minimal effect due to oil price hikes. The evidence is inconsistent with previous studies (Abdul Hadi, et al., 2009; Wang, et al., 2010) which found significant relationships between oil price, gold price, and stock market performance. Nevertheless, these studies covered different periods from the current study. For example, the study by Abdul Hadi et al. (2009) employed data from 1986 to 2006. This period did not include the 2008 global financial crisis, which if included may result in a different effect in the study.

In this study, FBMKLCI was used as a proxy for stock market performance. The use of FBMKLCI as a proxy is identified as a limitation of this study. This is because FBMKLCI comprises the 100 largest firms listed on Bursa Malaysia. Therefore, the use of FBMKLCI might not be appropriate. Therefore, future research may consider using other indices to proxy the stock price performance. This could lead to another possible angle that could be explored for future research. It might be interesting for example, if future researchers could look into whether these variables have different effects on different sectors. In addition, it would also be great if further research can be carried out to explore the causality effect, specifically to investigate whether stock price movements cause changes in the commodity prices or the changes in commodity prices lead to stock price movements.

In conclusion, this study indicated cointegrating relationships between interest rate, exchange rate, stock price performance, and each of the selected commodities. Thus, in pursuing the economic objectives, such as to achieve low inflation rate or full employment, the policy makers may also want to look at the impact of rules or policies on these variables. This is because the implementation of related policies should be carried out with caution as they may have a negative impact on the stock market. Consequently, a weak stock market may also lead to a weak economic condition.

\section{References}

Abdul Hadi, A. R., Yahya, M. H., \& Shaari, A. H. (2009). The effect of oil price fluctuations on the Malaysian and Indonesian stock markets. Asian Journal of Business and Accounting, 2, 69-91.

Bekhet, H. A., \& Mugableh, M. I. (2012). Investigating equilibrium relationship between macroeconomic variables and Malaysian stock market index through bounds tests approach. International Journal of Economics and Finance, 4(10), 69-81.

Fama, E. F. (1970). Efficient capital markets: A review of theory and empirical work. Journal of Finance, 25(2), 383-417.

Fama, E. F. (1991). Efficient capital markets: II. The Journal of Finance, 46(5), 15751617.

Hamilton, J. D. (1983). Oil and the macro economy since World War II. Journal of Political Economics, 92(2), 228-248.

Hussin, M. Y. M., Muhammad, F., Abu, M. F., \& Awang, S. A. (2012). Macroeconomic variables and Malaysian Islamic stock market: A time series analysis. Journal of Business Studies Quarterly, 3(4), 1-13.

Ibrahim, M. H., \& Wan Yusoff, S. W. (2001). Macroeconomic variables, exchange rate and stock price: A Malaysian perspective. IIUM Journal of Economics and Management, 9, 141163.

Kapusuzoglu, A. (2011). Relationships between oil price and stock market: An empirical analysis from Istanbul stock exchange (ISE). International Journal of Economics and Finance, 3, 99-106. 
Lee, C. L., Boon, T. H., \& Baharumshah, A. Z. (2001). The stock market, macroeconomic fundamentals and economic growth in Malaysia. Asia Pacific Journal of Economics and Business, 5(2), 44-55.

MacDonald, R. \& Ricci, L. (2003). Estimation of the Equilibrium real exchange rate for South Africa, IMF Working Paper WP/03/44

Majid, M. S. A., \& Yusof, R. M. (2009). Longrun relationship between Islamic stock returns and macroeconomic variables. Humanomics, 25(2), 127-141.

Maysami, R. C., Howe, L. C., \& Hamzah, M. A. (2004). Relationship between macroeconomic variables and stock market indices: Cointegration evidence from stock exchange of Singapore's all-s sector indices. Jurnal Pengurusan, 24, 47-77.

Narayan, P. K. (2005). The saving and investment nexus for China: Evidence from cointegration tests. Applied Economics, 37, 1979-1990.

Mohd Nasir, N., Hassan, N. M., Nasir, Z. A., \& Harun, M. F. M. (2012). Macroeconomic factors as the determinants of stock market return in Malaysia: Multivariate co-integration and causality analysis. Paper presented at the Terengganu International Business and Economics Conference 2012, Kuala Terengganu, Terengganu, Malaysia.

Muhammad, J., Ghuslan, M. I., \& Jusoff, K. (2009). Long-run relationship between Malaysian stock market and agriculture sector. Interdisciplinary Journal of
Contemporary Research in Business, l(6), 157-171.

Patel, S. (2012). The effects of macroeconomic determinants on the performance of the Indian stock market. NMIMS Management Review, 22, 117-127.

Rahman, A. A., Sidek, N. Z. M., \& Tafri, F. H. (2009). Macroeconomic determinants of Malaysian stock market. African Journal of Business Management, 3(3), 95-106.

Ross, S. A. (1976), The arbitrage theory of capital asset pricing. Journal of Economic Theory, 13, 341-360.

Sadorsky, P. (1999). Oil price shocks and stock market activity. Energy Economics, 21, 449-469.

Shrestha, M. B., \& Chowdhury, K. (2005). $A R D L$ modeling approach to testing the financial liberalization hypothesis. Economics Working Paper Series 2005, University of Wollongong.

Valadkhani, A., Chancharat, S., \& Havie, C. (2009). Analysing the impact of international stock markets and macroeconomic variables on the thai stock market. The Business Review, Cambridge, 12(2), 50-56.

Wan Mahmood, M. W., \& Dinniah, N. M. (2009). Stock returns and macroeconomics variables: Evidence from the six Asian-Pacific countries. International Research Journal of Finance and Economics, (30), 154-164.

Wang, M. L., Wang, C. P., \& Huang, T. Y. (2010). Relationships among oil price, gold price, exchange rate, and international stock markets. International Research Journal of Finance and Economics, 47, 83-92. 